\title{
Case Report of a Parotid Benign Lymphoepithelial Cyst
}

\author{
Tilal Salah¹, Yousif I Eltohami2*, Ahmed Halawi ${ }^{3}$, Ahmed M Suliman² and Abosofyan S Atta ${ }^{4}$ \\ ${ }^{1}$ Al-Yarmouk College Department of Oral and Maxillofacial Surgery, Sudan \\ ${ }^{2}$ Faculty of Dentistry University of Khartoum, Sudan \\ ${ }^{3}$ Faculty of Dentistry, National Ribat University, Sudan \\ ${ }^{4}$ King Khalid University, College of Dentistry, Sudan
}

Submission: March 17, 2020; Published: April 13, 2020

*Corresponding author: Yousif I Eltohami, Faculty of Dentistry University of Khartoum, Sudan

Abstract

Benign Lymphoepithelial Cysts are Uncommon Developmental Lesions Occurring Usually Within Areas Including Lymphoid Tissue. They are Often Much Smaller in Size When Compared to Branchial Cysts Yet are Microscopically Indistinguishable and Many Authors Consider them to be the Same Entity. These Dysontogenic Lesions are Most Commonly Found in the Lateral Neck but May Also be Found in Salivary Glands (Mostly the Parotids). A 42 Years Old Female Reported to Khartoum Teaching Dental Hospital Complaining of a Left Parotid Region Swelling that is Persistent Even After Going Through a Previous Surgery for the Same Cause at Another Hospital. The Swelling was non-tender, Compressible and Diffuse with a Size of $4 \times 3.5 \mathrm{~cm}$. at the Time of Presentation Alongside a Normal Stensen's Duct and Facial Nerve Functions. Viral Screening was Negative for HIV, HCV and HBV. CT Imaging + Soft Tissue Contrast Revealed a Cystic Mass within the Left Parotid Gland. Cystic Enucleation was Done and HPE Revealed it to be a BLC.

Keywords: Benign Lymphoepithelial Cyst, Branchial Cyst, CT-Soft Tissue Contrast

\section{Introduction}

Benign lymphoepithelial cysts are uncommon lesions that develop within the oral lymphoid tissues. They are microscopically similar to cervical lymphoepithelial cysts (Branchial Cleft Cysts) but are generally much smaller in size and thus, some authors consider them to be the same entity. Yet, it is postulated-as described by Bernier and Bhaskar- that their origin is not embryonic and is instead a result of Degenerative Changes to Inclusions within Salivary Glands. Patients with BLC often complain of a unilateral painless, slowly- growing mass without any accompanying symptoms related to the facial nerve. peak age of onset being during $4^{\text {th }}$ to $5^{\text {th }}$ Decades with No Significant Gender Predilection Noted [1-6].

\section{Case Report}

\section{Clinical History of the Patient}

A 42 Years Old Female Reported to Khartoum Teaching Dental Hospital Complaining of a Left Parotid Region Swelling that is Persistent Even After Going Through a Previous Surgery for the Same Cause at Another Hospital. The Swelling was non-tender, Compressible and Diffuse with a Size of $4 \times 3.5 \mathrm{~cm}$. At the Time of Presentation (Figure 1) Alongside a Normal Stensen's Duct and Facial Nerve Functions. Overlying Skin was scarred from the previous operation as the patient reported. No associated lymphadenopathy was noted, and the thyroid gland was found unremarkable. Milking of the Stensen's Duct Revealed normal flow of saliva.

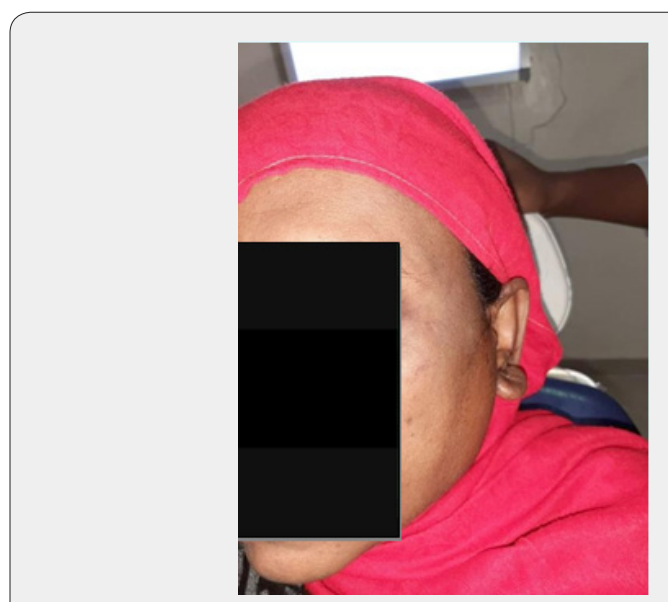

Figure 1: Non-Tender, Diffuse Left Parotid Area Swelling. 


\section{Provisional Diagnosis}

The Provisional Diagnosis was unclear as the patient reported being operated in another institution suggesting either incomplete removal or recurrence. Provisional diagnosis included Mucus retention cyst, Extravasation Cysts and Benign Salivary Gland tumors such as Pleomorphic Adenoma and Warthin's Tumor. An Orthopantomographic view was done yet revealed no abnormalities to be noted.

\section{Investigations Done}

a) Viral screening: Negative for HIV, HBV, HCV

b) Complete blood Count: Revealing Microcytic Hypochromic RBCs

c) Contrast-Enhanced Computed Tomography: Revealed a well- demarcated, thin-walled lesion measuring $4 \mathrm{~cm}$ x $3.5 \mathrm{~cm}$ (Figure 2).

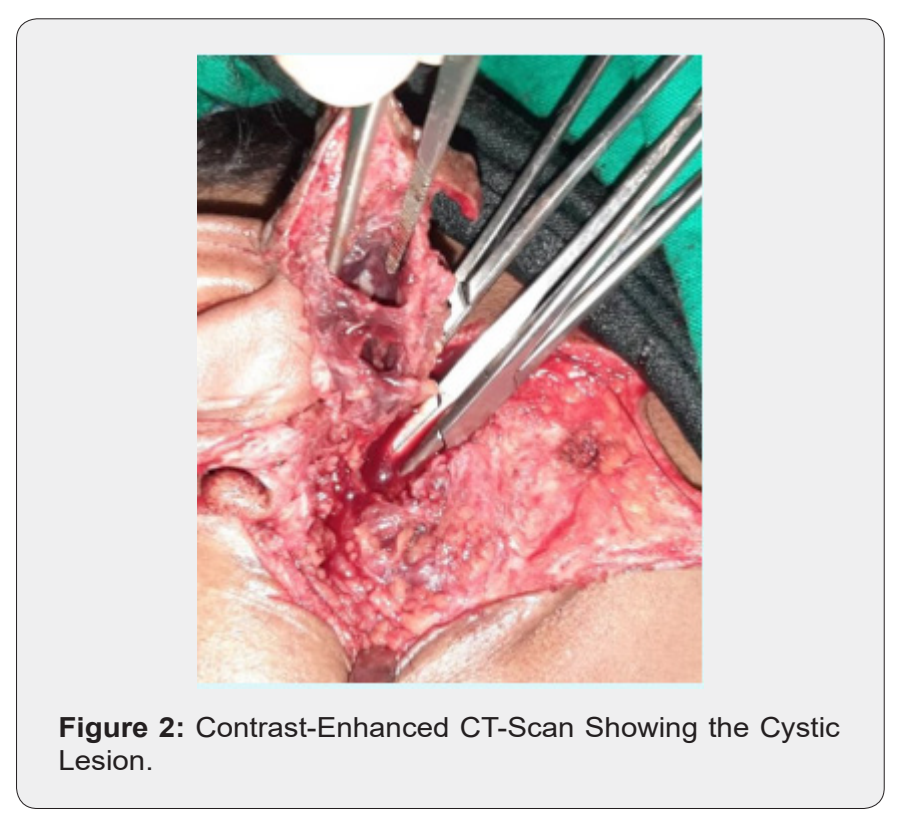

Findings were discussed with the patient and decision was made for cystic enucleation and partial superficial parotidectomy under general anesthesia was agreed upon.

\section{Treatment}

Under maximum possible aseptic conditions and after administering general anesthesia and proper draping of the patient, access to the cyst was made through an old scar of a previous operation. The cystic lesion was reached after careful combination of blunt and sharp dissection. Part of the cyst was notably inside the gland itself and thus, it was removed and submitted for histopathological examination (Figure 3). Previous Scar Tissue was Also Surgical Removed for better cosmetic outcome (Figure 4). The patient recovered uneventfully, and facial nerve was tested postoperatively proving to be fully functional.
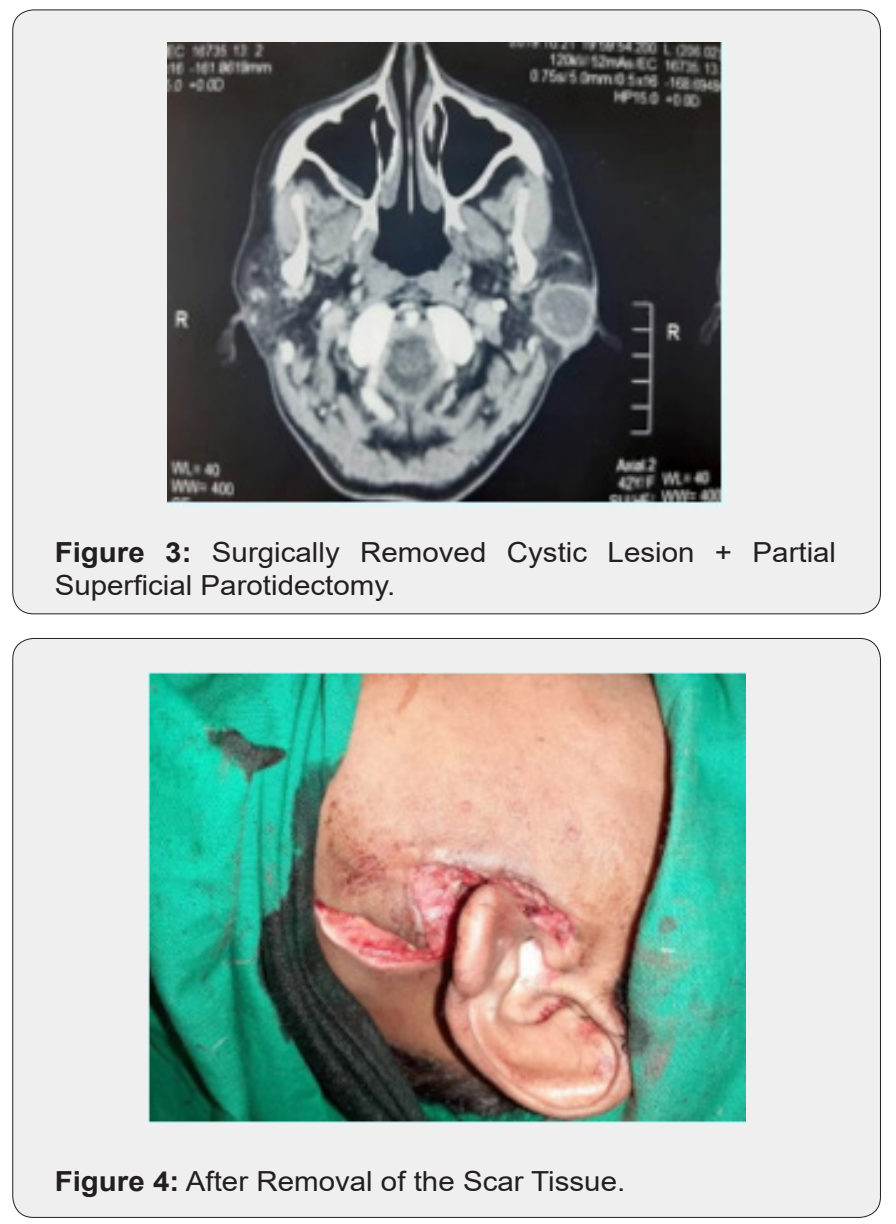

\section{Histopathological Report}

Histopathological Report of the Excisional Biopsy Revealed Thin cystic lining composed of ciliated columnar epithelium with normal adjacent salivary gland tissues and reactive lymphoid tissues. No evidence of malignancy noted. Specimen was suggestive of a Lymphoepithelial Cyst. Slow-growing painless (unless infected) swelling. The cystic nature of the swelling can hardly be recognized by physical examination alone.

\section{Discussion}

\section{Parotid Lymphoepithelial cysts often present as a unilateral}

Slow-growing painless (unless infected) swelling. The cystic nature of the swelling can hardly be recognized by physical examination alone.

\section{Incidence}

It is well known that lymphoepithelial cysts are generally considered to be rare as since the first report of such a case in 1895 by Hildebrant, approximately 70 cases were reported only. Since Hildebrant, 33 cases were Diagnosed by Fujibayashi after examining 5 reviews [6,7]. Majority of cases were unilateral and affecting the right parotid gland-on the contrary to the case at 
hand- with 44 years being the mean age of onset. This case was of a 42 years old female patient $[8,9]$.

\section{Site and Progression}

Generally Branchial Cleft Cysts affect the lateral cervical area deep to the sternocleidomastoid muscle. However, lymphoepithelial cysts can occur at any site with a lymphoid tissue component present in it. The parotid gland includes intraparotid lymph nodes embedded within thus, being a possible site for development of this type of cysts. Lymphoepithelial cysts may grow to reach considerable sizes enough to cause facial deformities.

\section{Etiopathogenesis}

The etiopathogenesis of branchial cleft cysts and lymphoepithelial cysts is a subject of great debate, many postulations have been made regarding the matter yet, to this day, controversy still exists. Branchial cleft cysts are said to originate following incomplete obliteration of the pharyngeal clefts and pouches with approximately $95 \%$ of the branchial cleft anomalies believed to arise from the second pharyngeal arch and the remaining $5 \%$ originating from the $1^{\text {st }}, 3^{\text {rd }}$ and $4^{\text {th }}$ branchial arches [10-12].

\section{Types}

Several types of cysts can be found within the parotid gland including:

i. Conventional Cysts (retention and extravasation).

ii. Congenital Cleft Cysts such as the lymphoepithelial cyst which may also be associated with AIDS.

iii. Dysgenetic Polycystic Disease of the Salivary Glands, affecting mainly the parotids bilaterally, more common in females of younger age groups.

iv. Salivary Gland Tumors with cystic presentation [13,14].

\section{Workup}

\section{Laboratory Studies}

No specific laboratory investigations needed.

\section{Imaging Studies}
a) Contrast Enhanced CT: 2- MRI.
b) Sinogram (if Sinus Tract Exists).
c) Ultrasonography.

\section{Procedures}

Fine-needle aspiration may help differentiate the cyst from other malignant conditions. Fine-Needle Aspiration Culture may aid in the selection of a proper antibiotic regimen for an infected cyst.

\section{Differential Diagnosis}

Differential diagnosis of parotid lymphoepithelial cyst include:

i. Warthin's Tumor.

ii. Pleomorphic Adenoma.

iii. Intramuscular Hemangioma.

iv. Lymphoma.

\section{References}

1. Weidner N, Geisinger KR, Sterling RT, Miller TR, Yen TS (1986) Benign lymphoepithelial cysts of the parotid gland. A histologic, cytologic, and ultrastructural study. Am J Clin Pathol 85: 395-401.

2. Bernier JL, Bhaskar SN (1958) Lymphoepithelial lesions of salivary glands; histogenesis and classification based on 186 cases. Cancer 11(6): 1156-1179.

3. Gnepp DR, Sporck FT (1980) Benign lymphoepithelial parotid cyst with sebaceous differentiation-Cystic sebaceous lymphadenoma. Am J Clin Pathol 74(5): 683-687.

4. Richardson GS, Clairmont AA, Erickson ER (1978) Cystic lesions of the parotid gland. Plast Reconstr Surg 61(3): 364-370.

5. Peel R, Gnepp DR (1985) Diseases of the salivary glands. In: Barnes L, editor. Surgical Pathology of the Head and Neck. Marcel Dekker: New York, USA pp. 550-552.

6. Joshi J, Shah S, Agarwal D, Khasgiwal A (2018) Benign lymphoepithelial cyst of parotid gland: Review and case report. J Oral Maxillofac Pathol 22(Suppl 1): S91-S97.

7. Fujibayashi T, Itoh H (1981) Lymphoepithelial (so-called branchial) cyst within the parotid gland. Report of a case and review of the literature. Int J Oral Surg 10: 283-292.

8. Rahman S, Shaari R, Hassan R (2006) Parotid lymphoepithelial cyst: A case report. Arch Orofac Sci 1: 71-75.

9. Camilleri AC, Lloyd RE (1990) Lymphoepithelial cyst of the parotid gland. Br J Oral Maxillofac Surg 28(5): 329-332.

10. Alves CA, Ribeiro Júnior O, Borba AM, Souza SC, Naclério-Homem MG (2011) Parotid lymphoepithelial cyst in non-HIV patient. J Clin Exp Dent 3(Suppl 1): e400-4003.

11. Marmary Y, Gomori JM, Nitzan DW (1990) Lymphoepithelial parotid cysts as presenting symptom of immunodeficiency virus infection: Clinical, sialographic, and magnetic resonance imaging findings. J Oral Maxillofac Surg 48(6): 981-984.

12. Maynard JD (1988) Solitary cysts of the parotid. Br J Surg 75(10): 1043.

13. Droese M (1981) Cytological diagnosis of sialadenosis, sialadenitis, and parotid cysts by fine-needle aspiration biopsy. Adv Otorhinolaryngol 26: 49-96.

14. Nisha VA, Parthiban J, Manigandan T, Amudhan A, Saravanakumar B (2014) Infected Parotid cyst-A case Report with Review of Literature. Bio sci Biotech Res Asia 11(1): 165-167. 
This work is licensed under Creative Commons Attribution 4.0 License DOI: 10.19080/ADOH.2020.12.555836
Your next submission with Juniper Publishers will reach you the below assets

- Quality Editorial service

- Swift Peer Review

- Reprints availability

- E-prints Service

- Manuscript Podcast for convenient understanding

- Global attainment for your research

- Manuscript accessibility in different formats (Pdf, E-pub, Full Text, Audio)

- Unceasing customer service

Track the below URL for one-step submission https://juniperpublishers.com/online-submission.php 